第 2 編 緩急車の衝撃, 振動, 騒音測定結果の分析

\author{
小 野 昭 雄*
}

\title{
WORKING CONDITIONS OF BAGGAGE TRAIN-CONDUCTORS
}

\author{
Report 2. Analysis of Shock, Vibration and Noise of Baggage
}

\begin{abstract}
Akio ONO†
In the previous report, the author demonstrated, using two kinds of questionnaire, that baggage conductors were faced with health problems resulting from their evening and night works and from poor working environmental conditions such as noise, vibration and shock.

In this report, the author wants to show another research in which noise, vibration and shock in the caboose were measured in order to compare the environmental conditions with the results of health questionnaires.

The results are as follows;

1. There were measured much more times of shock in the caboose than in the baggage car of the express train. Model "YO" of caboose had twice the shock in frequency of Model "KOKIFU" of caboose.

2. As to the strength of shock, more powerful shock was measured in Model "YO" than in Model "KOKIFU" or in the baggage car of the express train.

3. The vibration in these two kinds of caboose and in the baggage car exceeded the "allowable limit of vibration as a vehicle" reported by Oshima, and that of Model "YO" was even beyond the "limit of uncomfortable vibration" reported by. Meister.

4. As to noise, the baggage car of the express train had lower level of noise than these two kinds of caboose. The noise of these two kinds of car were beyond the threshold limit of noise in industry.

5. The results of the environmental investigation showed that baggage conductors on board the caboose pointed out correctly their poor working conditions in the answer to the questionnaire.
\end{abstract}

\section{I. 緒論}

列車乗務員に関する衛生学的研究の多くは, 車両の物 理的環境としての車両振動, 車両構造, 軌道の状況等の 全身振動による障害と乗り心地との関連についてなされ ており ${ }^{1 \sim 11)}$, 乗務員の労働条件との関連で健康問題を検 討したものは非常に少ない.また, 車両構造について

* 岡山大学医学部衛生学教室（主任 大平昌彦教授） 昭和 48 年 3 月 12 日受付

† Department of Hygiene, Okayama University Medical School

(Director: Prof. Masahiko Ohira)

Received for publication, March 12, 1973
も，運転室に関したものが多く ${ }^{12,13)}$ ，緩急車については 旅客列車との比較に拈いてなされている ${ }^{8 \sim 10)} に$ 過ぎず, 䋧急車独自の問題として研究, 調查したものはきわめて 少ない(0).

すでに第 1 編 ${ }^{14)}$ において指摘したごとく，列車乗務員 の中でも列車掛の勤務内容は, 非常に複雑・多岐にわた っており, その労働条件は運転乗務員と比較しても決し て恵まれているとはいえず，その上，最近の国鉄当局の 合理化の推進によりますます労働条件, 職場環境が悪化 しつつあり, 加えて「列車掛」の職種の固定化に伴な い, 他の職種への転換が困難になったことから, 列車掛 の職場環境としての緩急車について労衝衛生学的立場か 
ら検討することはきわめて重要な課題であるといわなけ ればならないであろう。

\section{II. 調 查 目 的}

列車乗務員として列車掛も勤務内容は不規則であり， 緩急車乗務に伴う衝撃, 振動, 騒音等によって, 乗務中 に数多くの外傷を含めた健康障害を受けていることを第 1 編 ${ }^{14)}$ で指摘した。さらに，これら不規則勤務と衝撃， 振動，騒音による健康障害に関して，列車掛が具体的な 改善要求を数多く指摘していることを報告した.

これら第 1 編に報告した列車脚が自ら指摘している緩 急車乗務による衝撃, 振動, 騒音の実態を物理的な測定 結果として明らかにする目的で調査を行なった。

また，これら緩急車の物理的環境の特性を明らかにす る目的で急行旅客列車最後尾の荷物車の測定結果との比 較を行ない検討を試みた。

\section{III. 調查対象および方法}

測定は急行貨物列車最後尾の緩急車内において岡山操 車場と吹田操車場との間で往路, 復路ともに行なった.

緩急車型式は, 岡山操車場 $\rightarrow$ 吹田操車場は 2 軸車でか つ独立した緩急車の「ヨ」型式, 吹田操車場 $\rightarrow$ 岡山操車 場はボギー車でコンテナを塔載する貨車の最後尾に乗務 室のある「コキフ」型式であった.

衝撃は Fig. 1 に示すよらな錘子を固定した板を列車 の進行方向に向って左側の側壁に固定し, 列車の進行方 向に向って座った測定者に感じられた進行方向の衝撃数 およびその際に錘子の示した角度を記録した。

振動は，ベガー製可動型振動計を用い，乗務室中央の 床面で発停車時, 停車中を除き 3 分間隔で測定した。測 定項目は, 振動加速度 $(\mathrm{g})$, 振幅変位 $(\mu)$ であった。 振動加速度と振幅変位より振動周波数 $(\mathrm{Hz})$, 振動速度 $(\mathrm{mm} / \mathrm{sec})$ を求めることができる ${ }^{15)} こ と は$ 知られてお り, 振動計に付属している付表により振動周波数と振動 速度とを求めた。

騷音は,リオン製簡易騒音計を用い乗務室中央の床上 約 $100 \mathrm{~cm}$ の位置で, 発停車時, 停車中を除き 3 分間隔 で測定した. 列車走行の変化が多く定常状態にないた め, JIS-Z-8731 による測定法によらず測定時の瞬間值を 読んだ.

コントロールとしての荷物車での測定は岡山 $\rightarrow$ 大阪間 で同様の方法で行なった。

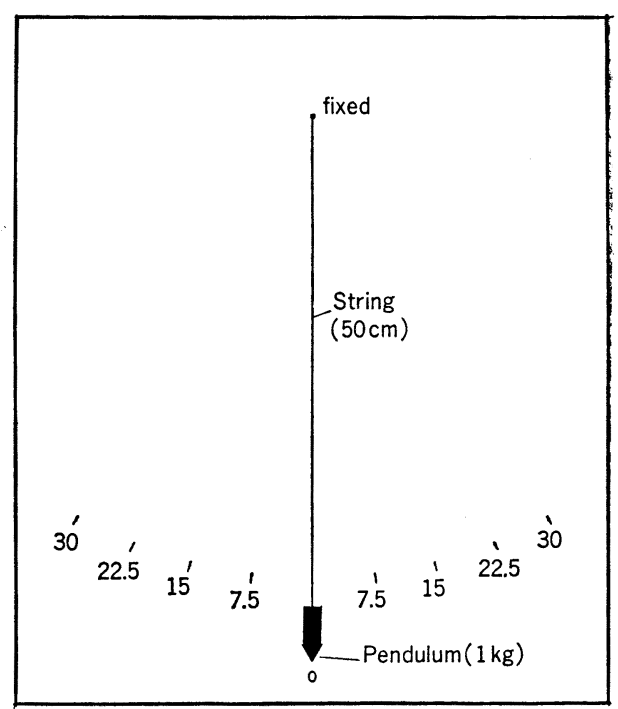

Fig. 1. Pendulum for measurement of shock.

\section{IV. 調查結果と考察}

\section{A. 衝撃}

衝撃数を勾配の急な区間のある三石〜西明石間と専用 線を走行する西明石〜塚本間にわけて比較すると， Table 1 に示すごとく荷物車は㖃急車に比べて衝撃数が 少ない。また「コキフ」と「ヨ」とを比べると前者は 後者の約 $1 / 2$ の頻度であった。 また, 錘子が $10^{\circ}$ 以上ふ れた衝撃数をみると, 荷物車,「コキフ」では全体の半 数内外であったのに比べて「ヨ」では衝撃のほとんどを 占めていた.

荷物車の車両構造は客車に類似しており,また「コキ フ」はボギー車でかつ最も新しい型式の緩急車であるこ とから「ヨ」型式の緩急車はより衝撃を受けやすく，か， つ大きな衝撃を受けやすいことが認められた.

現在多く使用されている「口フ」拉よび「ヨ」型式の 緩急車はともに 2 軸車であり, 車両構造に大きな相違が なく，乗務中の列車掛の負傷が多いことと一致している 点, これら 2 車種の緩急車の使用については問題が残さ れる。

列車烓自身がこのことについては列車速度, 列車編成 等との関連で多岐にわたる改善項目を指摘しており ${ }^{14)}$, その妥当性が認められたといえよう.

\section{B. 振 動}

振動加速度の分布は，Fig. 2 亿見るごとく「コキフ」 と荷物車は.1.0 g 未満であるのに比して「ヨ」ではより 大きな振動加速度の占める率の高いのが認められる. 
Table 1. Shock measured in caboose and boggage car.

\begin{tabular}{|c|c|c|c|c|c|}
\hline $\begin{array}{l}\text { Course where the measure- } \\
\text { ment was carried out }\end{array}$ & $\begin{array}{l}\text { Location used in } \\
\text { this report }\end{array}$ & Model of caboose & $\begin{array}{l}\text { Number } \\
\text { of } \\
\text { shocks }\end{array}$ & $\begin{array}{c}\text { Number } \\
\text { of shocks/ } \\
10 \mathrm{~km}\end{array}$ & $\begin{array}{l}\text { Number } \\
\text { of shocks } \\
\text { over } 10^{\circ}\end{array}$ \\
\hline \multirow{2}{*}{$\begin{array}{l}\text { OKAYAMA marshaling yard } \\
\qquad \\
\text { SUITA marshaling yard }\end{array}$} & $\begin{array}{l}\text { MITSUISHI* } \\
\quad \text { NISHI-AKASHI }\end{array}$ & \multirow{2}{*}{ YO } & 47 & 6.0 & 45 \\
\hline & 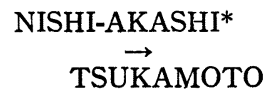 & & 56 & 10.9 & 47 \\
\hline \multirow{2}{*}{$\begin{array}{l}\text { SUITA marshaling yard } \\
\qquad \begin{array}{l}\rightarrow \\
\text { OKAYAMA marshaling yard }\end{array}\end{array}$} & $\begin{array}{l}\text { TSUKAMOTO } \\
\text { NISHI-AKASHI }\end{array}$ & \multirow{2}{*}{ KOKIFU } & 29 & 5.6 & 12 \\
\hline & $\begin{array}{l}\text { NISHI-AKASHI } \\
\overrightarrow{\text { MITSUISHI }}\end{array}$ & & 29 & 3.7 & 12 \\
\hline \multirow{2}{*}{ OKAYAMA $\rightarrow$ OSAKA } & 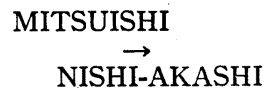 & \multirow{2}{*}{$\begin{array}{l}\text { baggage car of } \\
\text { express train } \\
\text { (as the control) }\end{array}$} & 18 & 2.3 & 7 \\
\hline & $\begin{array}{l}\text { NISHI-AKASHI } \\
\text { TSUKAMOTO }\end{array}$ & & 14 & 2.7 & 8 \\
\hline
\end{tabular}

* Distance of each location is as follows MITSUISHI-NISHI-AKASHI $78.6 \mathrm{~km}$ NISHI-AKASHI-TSUKAMOTO $51.5 \mathrm{~km}$

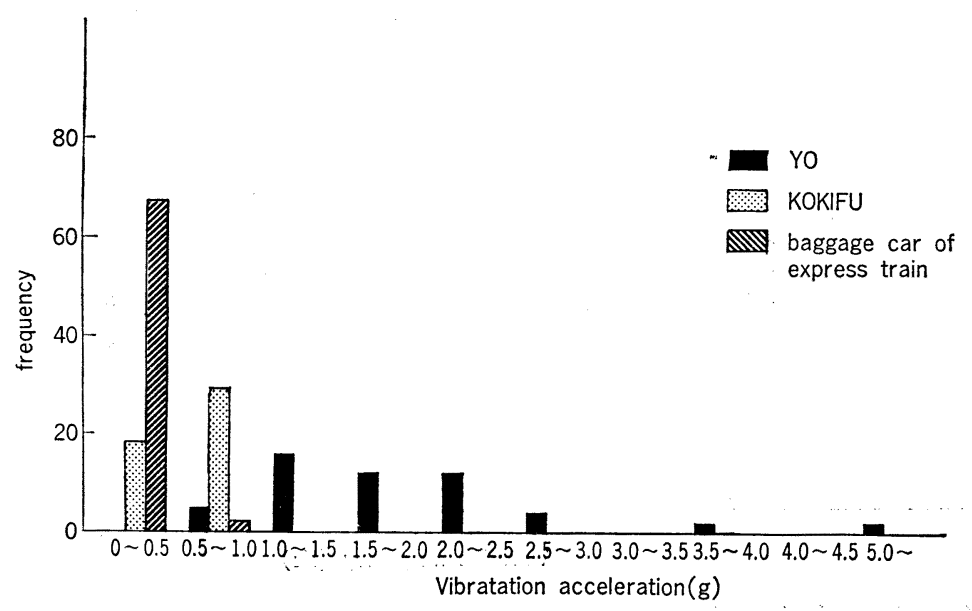

Fig. 2. Distribution classified by frequency and vibration acceleration.

振幅変位の分布は, Fig. 3 に見るごとく，「ヨ」と 「コキフ」がほほ類似の分布を示し, 荷物車ではこれら 2 種の緩急車に比して小さくなっている.

振動加速度と振動周波数の組み合せで乗心地の検 討 $^{2 \sim 7)}$, 暴露限界等の検討 ${ }^{16)}$ が行なわれてているが，今回
の測定では振動方向についての分析を行なっていないた めこれらについては検討していないが「「ヨ」では, 振 動加速度が大きいことから乗心地保数が「非常に悪い」゙ 限度すら越えていることが考えられる。

振動の恕限度について振動周波数と振幅变位との組み 


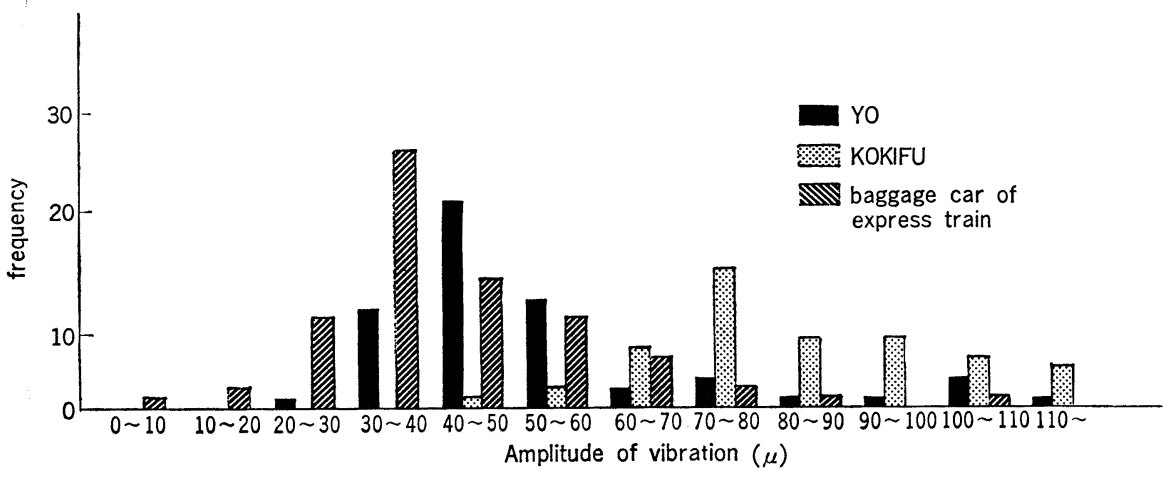

Fig. 3. Distribution classified by frequency and amplitude of vibration.

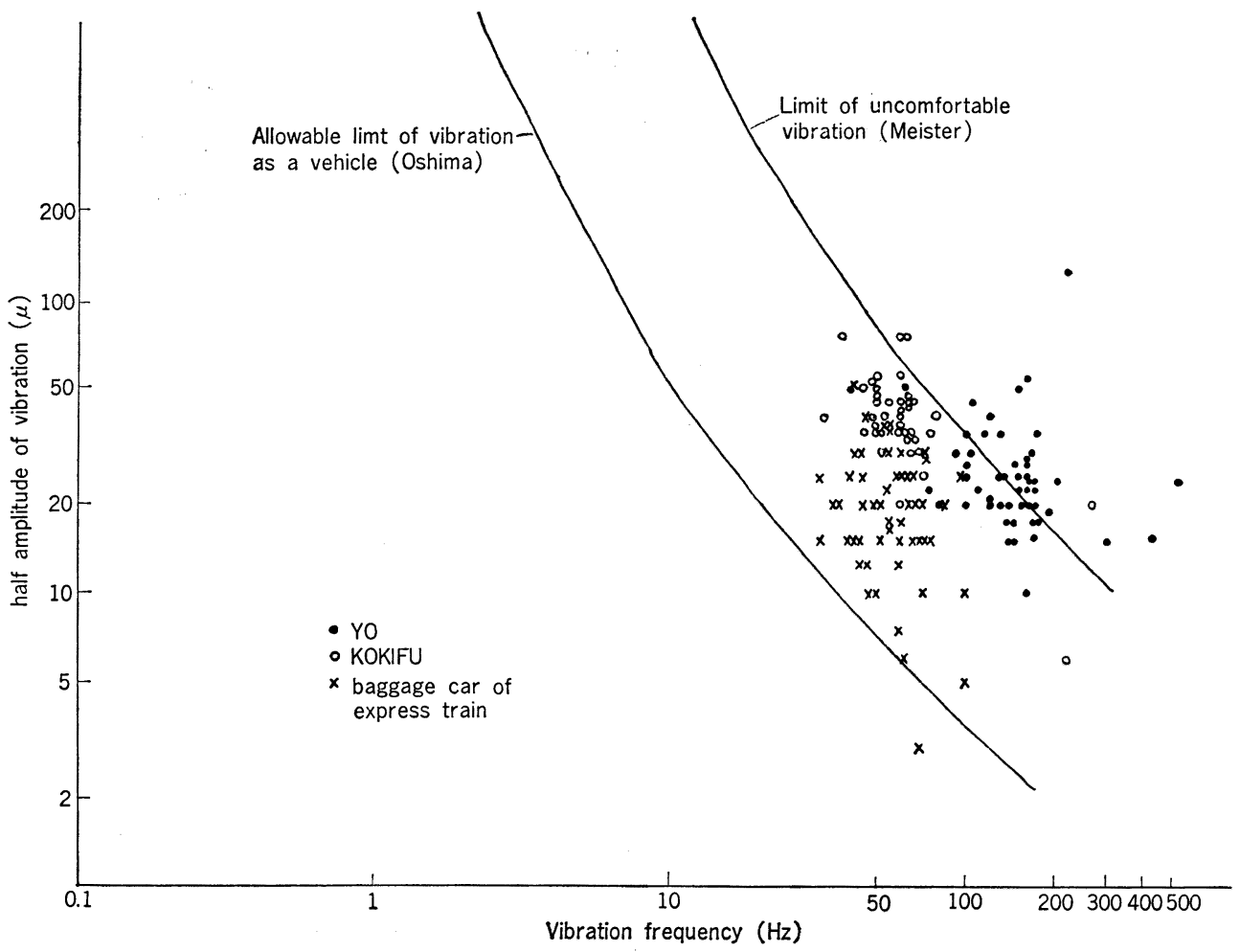

Fig. 4. The relationship between the measured vibration and the allowable limit.

合せで検討すると，Fig. 4 と示すごとくいずれの被測定 車も大島吾)の “乗物としての恕限度”を越えており, 「コキフ」では Meister ${ }^{17)}$ の報告する “非常に不快感を お゙きえる限度”に接近しており,「ヨ」ではこの限度を る越える回数が大幅に増加していた.

全身の振動感覚についての大島の実験結果 ${ }^{18)}$ を参考に
測定結果より 振幅変位 $\times$ 振動速度 $\times 60$ の值を求め各 被調査車についてその頻度を求めると, Fig. 5. と示す ごとく，荷物車では大島の報告する ${ }^{18)}$ “強く感ずる程度” までであるのに対して，「コキフ」では“不快感をおぼ える程度”に接近し，「ヨ」ではしばしばこれを越える のが認められた。 


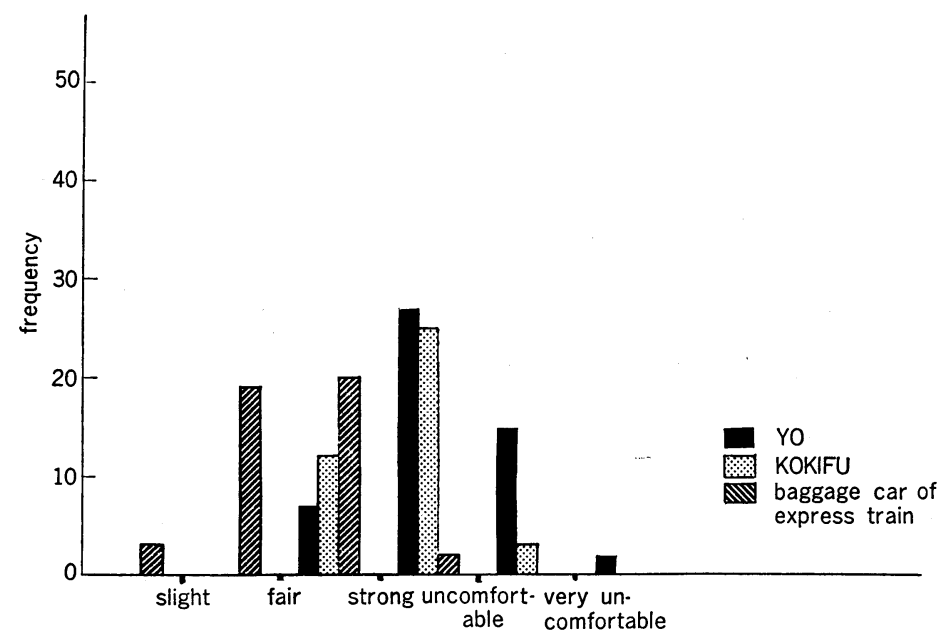

Fig. 5. Intensity of feeling a shock.

Table 2. Noise measured in caboose and baggage car.

\begin{tabular}{|c|c|c|c|c|c|c|}
\hline $\begin{array}{l}\text { Course where the measurement } \\
\text { was carried out }\end{array}$ & $\begin{array}{l}\text { Model of } \\
\text { caboose }\end{array}$ & $\begin{array}{l}\text { Number of } \\
\text { measurement }\end{array}$ & Maximum & Minimum & Average & Deviation \\
\hline $\begin{array}{l}\text { OKAYAMA marshaling yard } \\
\text { SUITA marshaling yard }\end{array}$ & YO & 54 & $\begin{array}{c}\mathrm{dB}(\mathrm{C}) \\
107\end{array}$ & $\begin{array}{c}\mathrm{dB}(\mathrm{C}) \\
86\end{array}$ & $\begin{array}{l}\mathrm{dB}(\mathrm{C}) \\
103.5\end{array}$ & $\begin{array}{l}\mathrm{dB}(\mathrm{C}) \\
3.76\end{array}$ \\
\hline $\begin{array}{l}\text { SUITA marshaling yard } \\
\text { OKAYAMA marshaling yard }\end{array}$ & KOKIFU & 47 & 108 & 80 & 101.3 & 5.66 \\
\hline OKAYAMA $\rightarrow$ OSAKA & $\begin{array}{l}\text { baggage car of } \\
\text { express train } \\
\text { (as the control) }\end{array}$ & 69 & 108 & 85 & 98.3 & 3. 72 \\
\hline
\end{tabular}

大島 ${ }^{17,18)}$ の実験的研究による恕限度, 振動 感覚の 報 告, $\mathrm{ISO}^{16)}$ の全身振動の基準の決定は, 全身振動に暴露 される労働者の健康障害の実態をるとに決定されていな い点に問題点があり, 今回の調査結果からも単なる実験 結果が労働者の健康障害をよりよく反映しているとはい えない.

全身への振動負荷により胃腸症状や腰痛等が増加する

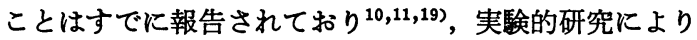
報告されている “不快感をおぼえる程度”から“非常に 不快感を抹ぼえる程度”に至る全身への振動負荷が，不 規則な勤務状況とも重なって列車掛の消化器系, 視器系 の疾患および腰痛の既往を高くし, 強い全身疲労の訴 え ${ }^{14)}$ になていると考えられる.

加えて, 列車速度の増加により振動が強くなることが

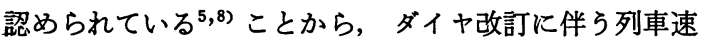

度の上昇 ${ }^{20)} に よ り$ 全身振動負荷がさらに増加することが 推测され得る.

\section{C. 騷 音}

測定結果は Table 2 に示すごとくであり，いずれの 被測定車両に拈いても8時間暴露の際の許容基準として

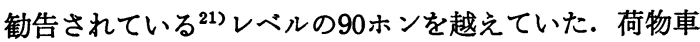
の平均値が緩急車の平均值に比べてやや低かったが統計 的な有意差は認められなかった。

既往歴として難聴を報告した者は少ないが(14)，経験年

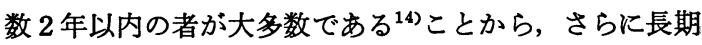
の持続的な暴露によって障害の発生しうることが予想さ れる.

\section{V. 結 論}

労働環境要因のらちで列車掛の改善要求の強かった衝 
撃，振動，㢦音について測定を行なった。

調査結果を要約すると以下のごとくになる.

1) 緩急車の衝撃の頻度は荷物車に比して高く，「ョ」 と「コキフ」とを比較すると前者は後者の約 2 倍の頻度 で衝撃を受ける回数が多かった。

2）「ヨ」では荷物車および「ュキフ」に比べて強度 の衝撃を受ける回数が多かった.

3）緩急車の振動は“乗物としての恕限度”を越えて おり，現在多く使用されている「ヨ」では“不快感をお ぼえる程度”をも越えていた，比較対照として測定した 荷物車でさえも乗物として快適とはいえない。しかし， 全身振動の許容基準については労働者の健康障害の実態 をもとに決定されるべきである。

4 ）騒音は荷物車の平均值が緩急車の平均值に比べて やや低いが，いずれの被測定車両とも騒音レベルにおい て許容基準を越えていた。

5）これら衝撃，振動，騒音の状況は，すでに列車掛 によって指摘されている内容とよく一致しており，乗務 に伴う健康障害の一因となっていることが考えられ，緩 急車構造の改善が列車速度, 列車編成等との関連で多岐 にわたる再検討を必要としていると考えられる。

調查に当たってご協力いただいた国鉄労働組合岡山地方 本 部 の列車陟の方々，および適切なご指導，ご助言をいただいた岡 山地方本部執行部の方々に深甚の謝意を表します。 また，湘定 に際しご嗳助をいただいた岡山大学医学部衛生学教室 の吉田健 男講師，小河孝則技官に深甚の謝意を表します。

稿を終えるに当たり，終始適切なご指導，ご校閲をいただい た大平昌彦教授，青山英康助教授に深甚の謝意を表します。

（なお，この論文の要旨は昭和 47 年 4 月，第 45 回日本産業衛生 学会総会において報告した.)

\section{文献}

1）穂坂 衛, 他：乗心地の量的表現とその計測方法，鉄道
業務研究資料，8(7)：13-16，1951。

2) 松平 精: 車両の乗心地, 車両技術, 59: 2-7, 1962.

3）後藤尚男, 他：ボギー車の振動・乗り心地保数之軌道構 造に関する実験的一考察, 鉄道線路, 10(9)：23-28, 1960.

4）三芳功達：車両振動の湘定および判定法 (2), 鉄道技術 研究資料, $28(4) ： 48-49,1971$.

5）油井只朝：電気機関車の振動，機械の研究，19(1)：255 -262, 1967.

6） 三芳功達：新幹線電車の振動，機械の研究，19(1)：263 -268, 1967.

7）三芳功達：左右振動に対する乗りごこち基準（その 1), 铁道技術研究資料, $24(1): 27,1967$.

8）東京北局保線作業機械化推進チーム：東北本線に括ける 列車動摇の測定, JREA, 13(2): 7167-7171，1970.

9）安倍三史，他：札幌市交通局從業員，特に乗務員につい ての労衝衛生学的観察 第 2 編 冬期に拈ける調查, 北方 産業衛生, 11：18-31，1956.

10）岡田 晃：振動の生体に及注す影響について，北方産業 衛生, 14：17-41，1957.

11）岡田 晃：振動の人体への影響, 労働の科学, $25(7)$ : 10-14, 1970.

12）橋本邦衛, 他: 動力車運転室の人間工学 (1), 鉄道労働 科学, 16: $39-54,1964$.

13）牧林 功：新幹線電車の運転と疲労について, 労働の科 学, 22(5): 28-31, 1967 .

14）小野昭雄：列車掛の労働条件 第 1 編 アンケート調査 を中心とした調査結果, 産業医学, 15(2)：165-172, 1973.

15）岡田 晃, 他: 强音, 振動・衝撃の影響と対策, 36-37, 人間と技術社, 東京, 1970 .

16) International Organization for Standardization: Guide for the evaluation of human exposure to whole-body vibration, 1972.

17）大島正光：生体振動論, 104, 東京大学出版会, 東京, 1969.

18）大島正光：生体振動論， 17, 東京大学出版会, 東京, 1969.

19）岡田 晃, 他：騒音, 振動・衝撃の影響と対策, 279284, 人間と技術社, 東京, 1970 .

20）青山英康, 他：EL 乗務員の労働条件, 産業医学, 13 (2) : 101-114, 1970.

21）日本産業衛生協会：許容濃度等の勧告, 産業医学, 14 (5) : 505-506, 1972. 